\title{
ZINTEGROWANE PODEJŚCIE W NAUCZANIU JĘZYKA OBCEGO
}

\author{
AN INTEGRATED APPROACH TO TEACHING \\ A FOREIGN LANGUAGE
}

\author{
ANTONI PALIŃSKI
}

\begin{abstract}
This article deals with two of the four primary language skills - listening and reading. The author tries to show not only differences but also similarities between these two receptive language skills, as research has shown that they are very close to one another and have much in common, especially in terms of psychological aspects. The author draws readers' attention to the fact that both processes - listening and reading - are connected with acquiring and understanding information, entail a critical and creative interpretation of a given text, have similar structure as well as require much concentration and ability to read between the lines, and, furthermore, to understand what is not said or written directly. It is suggested that an integrated approach should be incorporated into the foreign language teaching process, as there are clear similarities between the two aforementioned language skills, especially in the psychological dimension.
\end{abstract}

Antoni Paliński, Akademia Humanistyczno-Ekonomiczna w Łodzi, Łódź - Polska.

Dotychczasowe badania nad działalnością mowną (komunikacją/komunikowaniem się) człowieka niezbicie dowodzą, iż przy określonej autonomii poszczególnych sprawności językowych istnieją równocześnie między nimi ścisłe związki, innymi słowy: można mówić o określonych związkach i zależnościach między nimi.

Wzajemne związki i wpływy zdeterminowane są, po pierwsze, tym, że u podstaw każdej formy komunikacji językowej znajduje się

złożony system mniej lub bardziej synonimicznych środków wyrażania, w określony sposób skorelowanych ze sobą i, po drugie, mechanizmy recepcji i produkcji mowy nie występują w izolacji, a na odwrót, stanowią całościową strukturę psychiczną człowieka, są względem siebie komplementarne ${ }^{1}$.

${ }^{1}$ Н.И. Г е з, О взаимосвязанном обучении реиептивным видам речевой деятельности, [w:] Психология и методика обучения устной речи в языковом вузе. Сборник научных трудов, вып. 142, Москва 1979. 
Niebagatelne były też ustalenia czy konstatacje, że opanowanie poszczególnych aspektów języka (elementów fonetycznych, leksykalnych, gramatycznych) nie zapewnia jeszcze skutecznego i fortunnego komunikowania się. Nie zapewnia dobrego funkcjonowania tej złożonej działalności mownej nawet dość wysoki stopień ukształtowania poszczególnych sprawności językowych. Komunikacja/komunikowanie się jako system ma inne cechy niż suma elementów wchodzących w jego skład. Inaczej mówiąc, zdanie czy dyskurs nie jest tylko sumą znaczeń użytych słów².

Efektywna komunikacja językowa polega często na umiejętności wykorzystania lub rozumienia, oprócz środków językowych, różnych zachowań pozajęzykowych, takich jak gesty, mimika itd., ilustrujących treść wypowiadanych sądów i intencji.

Komunikacja językowa, co jest niezwykle istotne, nacechowana jest kulturowo. Kompetencja kulturowa (międzykulturowa) jest nabywana w toku socjalizacji (w tym i nauki języka obcego).

Wśród czynników determinujących efektywną komunikację wymienia się również warunki, w których ona przebiega; niektóre z nich utrudniają porozumiewanie się (tzw. szumy), a inne ułatwiają (redundancja w aktach komunikacji językowej).

Powyższe ustalenia stały się między innymi podstawą do sformułowania dyrektyw glottodydaktycznych o konieczności rozwijania kompetencji komunikacyjnej w języku obcym rozumianej jako posiadanie wiedzy i umiejętności tworzenia wypowiedzi, które są zgodne z regułami kompetencji lingwistycznej i normami lingwopragmatycznymi wymaganymi $\mathrm{w}$ danej sferze komunikowania się i dla danego rodzaju dyskursu/tekstu.

Implikują także konieczność uwzględnienia, czy też wykorzystania podobnych mechanizmów mownych, leżących u podstaw funkcjonowania poszczególnych podsystemów i sprawności językowych w pracy nad akwizycją języka obcego.

Szczególnie bliskie ze względu na psychologiczną charakterystykę są słuchanie i czytanie, które, najogólniej biorąc, wypełniają podobną funkcję komunikatywną i bazują na podobnych mechanizmach - mechanizmach recepcji. Znajomość tych mechanizmów stanowi warunek podstawowy tworzenia racjonalnych kursów równoległego, zintegrowanego nauczania - w tym przypadku nauczania/uczenia się słuchania i czytania.

Drugi warunek, którego spełnienie jest konieczne - to ścisłe zaprogramowanie procesu nauki, uwzględniającego zarówno wspólne, podobne, jak i różne, odmienne aspekty tych czynności mownych. Winny być też stworzone optymalne warunki dla transferu nawyków i umiejętności z jednej formy działalności mownej na drugą.

${ }^{2}$ H. K o m o r o w s k a, Testy w nauczaniu języków obcych, Warszawa 1984. 
Każda czynność mowna, jak wiadomo, charakteryzuje się trzypoziomową strukturą ${ }^{3}$. Pierwsza jej faza, motywacyjno-inicjująca, realizowana jest przez zespół potrzeb, motywów i celów. Jest to więc faza związana z antycypowaniem rezultatu. Drugi poziom struktury czynności - to część analityczno-syntetyczna, ukierunkowana na rozpoznanie warunków realizacji czynności i środków, przy pomocy których może być ona wykonana. Trzecia część - to faza wykonawcza, faza realizacji, przejawiająca się: a) w zrozumieniu bądź niezrozumieniu informacji zawartej w tekście lub b) w wywołaniu określonej reakcji werbalnej albo niewerbalnej.

Dla słuchania i czytania charakterystyczne jest to, iż sprawności te nie mają swej zewnętrznej realizacji. Realizacja zadań i celów dokonuje się dzięki złożonym operacjom wewnętrznym.

Inna charakterystyczna cecha obu sprawności receptywnych sprowadza się do tego, iż motywacyjno-celowościowy aspekt determinowany jest pośrednio czynnościami mownymi innych osób (mówiącego, piszącego). Słuchający i czytający ma do czynienia z gotowym już produktem - tekstem. Cel słuchania i czytania - to rozumienie tekstu, tzn. aktualizacja wcześniejszego poznania w stosunku do przedmiotów i osób, wykrycie związków i zależności w przedmiotach i zjawiskach przekazywanych przez tekst dźwiękowy lub graficzny.

Aczkolwiek nauka poświęciła już niemało uwagi analizie recepcji mowy, to jednak do chwili obecnej nie posiadamy $w$ pełni wiarygodnych i sprawdzonych eksperymentalnie danych o przebiegu procesów recepcji.

Proponowane są różne modele recepcji mowy, spośród których największe uznanie zdobyły sobie cztery: akustyczny (R. Jakobson), motoryczny (A. Liberman, L. Czystowicz), model analizy poprzez syntezę (M. Halle, K.N. Stevens, N. Chomsky) oraz analityczno-syntetyczny (A. Sokołow).

Analiza tych propozycji wskazuje, że w zasadzie rozpatrują one różne aspekty tego samego procesu i nawzajem nie tylko się nie wykluczają, ale na odwrót uzupełniają. Według I. Zimniej:

1) Wszystkie modele percepcji mowy ustnej i pisemnej obligatoryjnie zakładają transformację sygnału mownego, aż do artykułowania odbieranego tekstu w mowie wewnętrznej włącznie.

2) Wszystkie propozycje zakładają konieczność porównania percypowanego sygnału mownego $\mathrm{z}$ ich obrazami, matrycami utrwalonymi w pamięci długotrwałej.

${ }^{3}$ T. T o m a s z e w s k i, Wstęp do psychologii, Warszawa 1963; А.А. Л е о н т ь е в, Психолингвистические единицы и порождение речевого высказывания, Москва 1969.

${ }^{4}$ М.А. 3 и м н я я, Смысловое восприятие речевого сообщения, [w:] Смысловое восприятие речевого сообщения в условиях массовой коммуникации, Москва 1976. 
3) Wszystkie teorie recepcji mowy implikacyjnie lub eksplikacyjnie zakładają obecność w mowno-motorycznych i słuchowych analizatorach obrazu jednostek odbieranej mowy.

4) Wszystkie modele recepcji mowy implikacyjnie lub eksplikacyjnie zakładają podobieństwo procesów recepcji i produkcji mowy w zakresie gramatycznej i logicznej organizacji wypowiedzi.

5) Wszystkie teorie zakładają przyjęcie określonej jednostki analizy mowy, którą może być fonem/grafem lub słowo.

6) Większość teorii recepcji mowy zakłada linearny charakter opracowywania sygnałów mownych.

7) Większość teorii recepcji mowy a priori zakłada również tworzenie hipotez dotyczących znaczenia lub treści komunikatu na podstawie uwarunkowań kontekstualnych i sytuacyjnych.

A zatem w procesie odbioru tekstu mówionego/pisanego można wyróżnić następujące poziomy5:

1. Sensoryczny (nierelewantny dla znaczenia znaków językowych). Chodzi tutaj o wykrywalność dźwięków/znaków graficznych mowy. W procesie słuchania istotne są: intensywność dźwięków, tembr głosu i jego barwa, wysokość tonu podstawowego; w procesie czytania - wielkość i kształt liter, kolor druku, kolor papieru, oświetlenie tekstu.

2. Percepcyjny, na którym odbywa się recepcja fizycznych charakterystyk fonemów/ grafemów i ich połączeń, a także czynników umożliwiających segmentację mowy (intonacja, rytm, pauzacja; znaki przestankowe).

3. Apercepcyjny poziom, na którym następuje identyfikacja znaczeń słów i syntagm zdeterminowana pobudzeniem ośrodków mowy, będących magazynami obrazów słów i ich połączeń.

4. Prognostyczny - antycypowanie mającej nastąpić części tekstu na podstawie już odebranego fragmentu tekstu i doświadczenia językowego i życiowego odbiorcy.

5. Ustalania znaczeń. Po identyfikacji znaków językowych następuje ustalenie znaczeń wyrazów poprzez odniesienie ich do wyrazów znajdujących się w magazynie wewnętrznym recypienta, które reprezentują odpowiednie fragmenty rzeczywistości pozatekstowej. Można również wydedukować znaczenie nieznanego znaku złożonego - komunikatu lub poszczególnych zdań ze znaczeń mniejszych jednostek lub uściślić znaczenie danego tekstu poprzez uwzględnienie otoczenia kontekstowego wyrazu/wyrazów. Następnie po uwzględnieniu informacji przekazywanych przez wykładniki gramatyczne i intonację lub znaki interpunkcyjne następuje ostateczne zrozumienie treści.

5 В.Л. С к а л к и н, Основы обучения устной иноязыноои речи, Москва 1981; A. P a 1 i ń s k i, Niektóre problemy kształtowania umiejętności czytania w języku rosyjskim, Rzeszów 1979. 
6. Logiczny - ustalenie sensu komunikatu poprzez ustalenie związków między znaczeniem danego komunikatu a znaczeniem poprzednich, znalezienie ukrytego sensu, ustalenie prawdziwości/fałszywości stwierdzeń.

Akt słuchowego/wzrokowego odbioru mowy, w tym i obcojęzycznej, może być tylko wtedy skuteczny, jeśli opiera się na określonej percepcyjnej bazie słuchającego/czytającego, tzn. jeżeli słuchający/czytający włada niezbędnym repertuarem fonetycznych/graficznych, leksykalnych i gramatycznych nawyków, dzięki którym akt percepcji jest krótkotrwałym. Brak tej bazy czyni proces percepcji tekstu procesem dyskursywno-logicznym, a na przykład zwolnienie tempa przekodowywania słuchanego tekstu w znaczenia może uczynić ten proces mało efektywnym lub w ogóle uniemożliwić ustalenie zawartej w nim informacji. Inaczej rzecz się ma w procesie czytania, kiedy czytelnik $\mathrm{w}$ wypadku niezrozumienia lub utraty wątku może powrócić na nowo do fragmentu tekstu odczytanego już wcześniej.

A więc zarówno proces słuchania, jak i czytania przebiega na dwóch poziomach: a) na poziomie nieuświadamianych, zautomatyzowanych procesów psychofizjologicznych; b) na poziomie świadomości, czyli poziomie znaczeniowym, pozwalającym kojarzyć formę dźwiękową/graficzną z odpowiednim znaczeniem oraz posiadaną wiedzą i doświadczeniem życiowym.

Analiza porównawcza słuchania i czytania pozwala również ustalić i inne mechanizmy wspólne, a także różne leżące $\mathrm{u}$ ich podstaw. ${ }^{6}$

Ruchy oczu w czasie czytania wiersza tekstu z lewa na prawo, jak wiadomo, odbywają się nieregularnie, arytmicznie, wykonując szereg skoków przedzielonych przerwami spoczynkowymi - fiksacjami. Oprócz fiksacji i ruchów zwrotnych, oczy, w szczególności słabo czytających, wykonują również ruchy wsteczne, regresywne, co związane jest z niedokładnym lub błędnym ujmowaniem elementów tekstu lub złym zrozumieniem tekstu.

Podobne zjawisko można zaobserwować u słuchającego, słabo syntezującego odbierany tekst i nie dysponującego dostatecznym zakresem pamięci krótkotrwałej (operacyjnej). Zazwyczaj zapomina on początek lub inną część wypowiedzi i nie jest $\mathrm{w}$ stanie dokonać niezbędnych uogólnień, „nie nadąża" także za tempem.

Zarówno w procesie słuchania jak i czytania istotną rolę odgrywa słuch fonematyczny, antycypowanie i pamięć, aczkolwiek nie zawsze wypełniają one identyczną rolę.

Słuch fonematyczny jest niezbędnym warunkiem ukształtowania obrazów znaków językowych, koniecznych dla efektywnej "pracy” pamięci

${ }^{6}$ M. D a k o w s k a, Psycholingwistyczne podstawy dydaktyki języków obcych, Warszawa 2001. 
krótkotrwałej. Słuch stanowi również bazę tworzenia się nawyków artykulacyjnych, które nie tylko służą dla celów transformacji planu treści na plan ekspresji, lecz są również niezbędne w procesie recepcji, kiedy to dzięki artykułowaniu w mowie wewnętrznej odbieranego tekstu możliwa jest jego identyfikacja.

Dla słuchającego istotna jest również intonacja, umożliwiająca dokonywanie prawidłowej segmentacji tekstu i rozróżnianie typu zdania.

Podobnie ma się sprawa z czytaniem cichym tekstu. Również tutaj na etapie przygotowawczym występuje utajona artykulacja odbieranego tekstu.

Zarówno w procesie słuchania, jak i czytania w zależności od trudności/łatwości odbieranego tekstu oraz poziomu opanowania technicznej strony percepcji utajona artykulacja charakteryzuje się różną intensywnością.

Redukcja wymawiania wewnętrznego następuje wraz z rozwojem technicznych aspektów słuchania/czytania, kiedy to recepcja staje się procesem jednoaktowym. Jej intensywność maleje również wtedy, kiedy odbierany tekst jest dla słuchającego/czytającego prosty i w pełni zrozumiały.

Jeśli chodzi o czytanie głośne, to tutaj niezbędne jest całkowite opanowanie skojarzeń dźwiękowo-literowych, co nie może się dokonać bez udziału słuchu mownego.

Innym istotnym aspektem odbioru mowy jest umiejętność antycypowania, która jest integralną częścią każdej aktywnej działalności człowieka. Antycypowanie treści lub antycypacja językowa uwarunkowane są wiedzą i doświadczeniem słuchającego/czytającego, znajomością leksyki i związków wyrazowych. Następny czynnik ułatwiający prognozowanie to dostatecznie duża ilość wyrazów pochodnych $\mathrm{w}$ tekście oraz asocjacje semantyczne, którymi rozporządza odbierający tekst.

Wypowiedź ustna/pisemna składa się zazwyczaj z wielu elementów. Przy tym dla ustalenia znaczenia tych elementów i sensu całości konieczne jest, jak już było wspomniane, ustalenie stosunków wzajemnych zachodzących między nimi, stosunków logiczno-gramatycznych. Oznacza to, iż słuchający/czytający musi dysponować zdolnością przechowywania w pamięci poprzedzających fragmentów tekstu przynajmniej tak długo, dopóki nie odbierze dalszych fragmentów niezbędnych do ustalenia znaczenia całości. Następny problem dla słuchającego/czytającego - to utrzymanie $\mathrm{w}$ pamięci wszystkich elementów odebranego tekstu. Zapomnienie bowiem któregokolwiek z nich przed ustaleniem znaczenia całości powoduje niezrozumienie tekstu bądź zrozumienie błędne. A więc wydolność pamięci słownej, zdolność do utrzymywania przez określone odcinki czasowe usłyszanego/przeczytanego tekstu stanowi także niezbędny warunek prawidłowego odbioru mowy. 
Należy przy tym podkreślić - zaznacza M. Maruszewski - że przechowywanie to musi być bardzo ścisłe i obejmować nie tylko poszczególne elementy, lecz również porządek, w jakim zostały one odebrane - samo bowiem przestawienie elementów może stać się przyczyną zakłóceń odbioru

Najistotniejsze zadanie do wypełnienia ma przed sobą $\mathrm{w}$ tym zakresie pamięć operacyjna, a w szczególności jej rodzaj zwany pamięcią krótkotrwałą, bezpośrednią. Badania eksperymentalne wykazały, że pamięć może przechowywać odebrany fragment tekstu do 20 sekund, a liczba jednostek, które jest w stanie zapamiętać po jednorazowej prezentacji wynosi $7 \pm 2$ elementów. Jest to tak zwana magiczna liczba określona przez G. Millera ${ }^{8}$.

$\mathrm{W}$ procesie słuchania/czytania odbiorca wykonuje złożone czynności myślowo-mnemiczne, których efektywność zdeterminowana jest również wysoką koncentracją uwagi, podporządkowanej dążeniu do celu, jaki człowiek chce osiągnąć. $W$ procesach słuchania/ czytania występuje zarówno uwaga mimowolna, jak i dowolna. Uwaga mimowolna, wywołana przez wystąpienie silnego bodźca wpływającego na zainteresowania słuchającego/czytającego, jest znacznie rzadsza aniżeli uwaga dowolna powstająca pod wpływem świadomie nakreślonego celu. Wywołuje ona czynność psychiczną skierowaną na realizację celu.

Proces słuchania/czytania również ściśle wiąże się z określonymi uczuciami i emocjami, których źródłem jest strona znaczeniowa tekstu.

Kolejnym istotnym czynnikiem wpływającym na rezultat końcowy procesów słuchania/czytania czyli na zrozumienie tekstu (rezultat pozytywny) lub jego brak (rezultat negatywny czynności) są specyficzne właściwości tekstów. Chodzi tutaj o właściwości językowe i strukturalno-kompozycyjne tekstu. $Z$ problemem tym ściśle związane jest zagadnienie korelacji języka odbieranego tekstu z doświadczeniem językowym słuchającego/czytającego, jednym słowem, ze znajomością języka. Ustalono ponad wszelką wątpliwość, iż słuchający/czytający musi władać pasywnie dość dużym, bo liczącym około 3-7 tys. słów, zasobem leksykalnym, a także znać biernie, w zasadzie, całą gramatykę danego języka.

Celem końcowym zarówno słuchania, jak i czytania jest zrozumienie tekstu, zdobycie informacji. Zrozumienie tekstu następuje w wypadku, gdy zostały ustalone związki między przedmiotami i zjawiskami przekazane przez dany tekst.

Rozumienie opiera się na związkach czasowych wytworzonych w praktyce jednostki i stanowi ich aktualizację.

${ }^{7}$ M. M a r u s z e w s k i, Mowa a mózg. Zagadnienia neuropsychologiczne, Warszawa 1970, s. 198.

8 A.A. M i 11 e r, The Magical Number seven plus Or minus two, "Psychological Review" 1956. 
Warunkiem niezbędnym dla rozumienia tekstu słuchanego i czytanego jest posiadanie przez odbiorcę odpowiednio bogatego repertuaru skojarzeń fonicznych i graficznych z odpowiadającymi im znaczeniami. Z drugiej strony adekwatne rozumienie tekstów zdeterminowane jest przez posiadanie wspólnego lub podobnego zarówno dla nadawcy, jak i odbiorcy doświadczenia życiowego, względnie posiadaniem określonej sumy wiedzy na przedstawiony w tekście temat.

Dotychczasowe rozważania dotyczyły podobieństw procesów słuchania i czytania. Jednakże zarówno słuchanie, jak i czytanie charakteryzuje się określonymi specyficznymi właściwościami.

Czynnikiem zasadniczo różniącym proces słuchania i czytania są warunki, w których one przebiegają, ich różna modalność. Oto najważniejsze różnice:

1. Istotne znaczenie dla rozumienia mowy ma tempo. Tempo zbyt wolne i zbyt szybkie (przy słuchaniu) znacznie pogarsza rozumienie. Dowodzą tego liczne eksperymenty. Związane jest to $\mathrm{z}$ wydolnością pamięci krótkotrwałej albo zbyt silną, pełną artykulacją $w$ mowie wewnętrznej w wypadku słabo opanowanego języka. Może to być również trudny tekst. $\mathrm{W}$ procesie czytania tempo jest regulowane przez samego czytającego. Może on wybrać tempo najbardziej optymalne dla realizacji zadania komunikacyjnego realizowanego poprzez czytanie. Natomiast słuchający nie ma takiej możliwości. Tempo mowy dyktowane jest przez mówiącego. Jeżeli słuchający nie nadąża za tempem mowy, której słucha, zazwyczaj nie rozumie też w pełni jej treści i sensu' ${ }^{9}$.

2. Jedną z właściwości procesu słuchania w odróżnieniu od czytania jest jego krótkotrwałość, nieodwracalność i jednorazowość. Natomiast czas czytania zależy wyłącznie od indywidualnych cech osoby czytającej, znajomości języka i problematyki. Może ona w razie potrzeby korzystać ze słownika, encyklopedii czy innych pomocy. Słuchający, jeśli nie usłyszy, nie zrozumie niekiedy nawet pojedynczego wyrazu (np. kluczowego), nie jest $\mathrm{w}$ stanie wypełnić powstałych luk, co prowadzi zwykle, w najlepszym wypadku, do częściowego rozumienia tekstu.

3. Statyczność tekstu graficznego powoduje konieczność całkowicie samodzielniej próby jego dekodowania przez czytającego. W lepszej sytuacji znajduje się słuchający, który dzięki zawartym w tekście informacjom suprasegmentalnym ma to zadanie ułatwione.

4. Czynnikiem ułatwiającym proces analizy i syntezy tekstu pisanego jest to, iż czytający, w szczególności dobry czytelnik, dysponuje dostatecznie szerokim polem czytania. Umożliwia mu to ogarnianie wzrokiem całych segmentów tekstu, co w konsekwencji prowadzi do lepszej jego ana-

9 Б.А. Б е н е д и к т о в, Психология овладения иностранным языком, Минск 1974. 
lizy i rozumienia. Takiej możliwości nie ma słuchający ze względu na linearność czasową tekstu dźwiękowego. Jest to znaczne utrudnienie.

5. Dość istotna różnica między słuchaniem i czytaniem związana jest z tym, że recepcji słuchowej towarzyszą zazwyczaj różnego rodzaju przeszkody zewnętrzne: indywidualne właściwości osoby mówiącej (zła dykcja, sposób mówienia, opanowanie strony dźwiękowej języka itd.) oraz obiektywne: hałas, zbyt duża odległość. Przezwyciężenie tych trudności dla zrozumienia komunikatu językowego wymaga znacznego wysiłku ze strony słuchacza. Natomiast czytający może mieć jedynie trudności związane ze złą wyrazistością druku.

Reasumując, można konstatować, iż przedstawione w sposób ogólny zasadnicze właściwości psychologicznego odbioru obcojęzycznej mowy ustnej i pisanej wskazują nie tylko na ich specyficzne właściwości, ale także na dość istotne podobieństwa związane $\mathrm{z}$ ich rolą $\mathrm{w}$ procesie komunikacji językowej i z prawidłowościami funkcjonowania procesów recepcji i rozumienia tekstu zarówno słuchanego, jak i czytanego.

A ten fakt upoważnia do wysunięcia hipotezy, że pomiędzy sprawnościami receptywnymi istnieje dość znaczny transfer. Implikuje to tworzenie $\mathrm{w}$ znacznym stopniu wspólnej metodyki ich kształtowania, uwzględniającej analogiczne i specyficzne właściwości każdej z tych sprawności, co można osiągnąć realizując zasady nauczania zintegrowanego. A gdy uwzględnimy fakt, iż $w$ realnej komunikacji sprawności językowe występują łącznie, np. rozumienie tekstu audialnego i mówienie, czytanie i mówienie, produkowanie leksyki i pisanie itd., to podejście integracyjne w nauczaniu języka obcego znajduje pełne uzasadnienie.

Powyższe stwierdzenie nie oznacza, iż nauczanie aspektowe należy wyeliminować z procesu akwizycji języka. Wiąże się ono przede wszystkim z kształtowaniem nawyków językowych, kiedy to racjonalność nauczania, mająca teoretyczne uzasadnienie, zakłada skupienie uwagi $\mathrm{w}$ pracy nad określonym zjawiskiem języka. Jednakże po osiągnięciu określonego sformowania poziomu nawyku należy przejść do ćwiczeń o charakterze kompleksowym: quasi-komunikacyjnym i komunikacyjnym. Takie podejście, jak wskazują badania, jest wyżej oceniane także przez uczących się (studentów), którzy twierdzą, że „język jest jednością, więc nie można podzielić go na partie, a ponieważ używając języka, używamy wszystkich sprawności naraz, tak też powinniśmy się go uczyć"10. Zdaniem ankietowanych zajęcia prowadzone systemem czysto aspektowym są „nudne", a podział zajęć między wielu prowadzących może opóźniać swobodne posługiwanie się językiem i stwarza dość istotne problemy organizacyjne.

10 Cyt. za: K. B u c z e k, Etap początkowy w nauczaniu języka rosyjskiego studentów rozpoczynających akwizycje języka od podstaw. Niepublikowana praca doktorska, Rzeszów 2010, s. 94. 
